Eaton, S.B., Eaton, F. and Konner, M. 1997 Palaeolithic nutrition revisited. A 12 year retrospective on its nature and implications. European Journal of Clinincal Nutrition 51: 207-216.

Elphinstone, J.J. 1971 The health of Australian Aborigines with no previous association with Europeans, Medical Journal of Australia 2:293-302.

Gould, R.A. 1980 Living Archaeology. Cambridge: Cambridge University Press.

Gould, R.A. 1986 To have and have not: The ecology of sharing among hunter-gatherers. In N.M.Williams and E.S.Hunn (eds) Resource Managers: North American and Australian Hunter-Gatherers, pp. 69- 87. Canberra: Australian Institute of Aboriginal Studies.

Gould, R.A. 1996 Faunal reduction at Puntutjarpa Rockshelter, Warburton Ranges, Western Australia. Archaeology in Oceania 31:72-86.

O'Connor, S., Veth, P. and Campbell, C. 1998 Serpent's Glen Rockshelter: Report of the first Pleistocene aged occupation sequence from the Western Desert. Australian Archaeology 46:12-22.

Peile, A.R. 1997 Body and Soul: An Aboriginal View. Perth: Hesperian Press.

Schrire, C. 1972 Ethno-archaeological models and subsistence behaviour in Arnhem Land. In D.L. Clarke (ed.) Models in Archaeology, pp.653-70. London: Methuen.

Smith, P.A. and Smith, R.M. 1999 Diets in Transition: Huntergatherer to station diet and station diet to the self-select store diet. Human Ecology: An Interdisciplinary Journal 27(1):117-134.

Veth, P.M. 1993 Islands of the Interior: The Dynamics of Prehistoric Adaptations with in the Arid Zone of Australia. Ann Arbor: International Monographs in Prehistory.

Walshe. K. 2000 Carnivores, taphonomy and dietary stress at Puntutjarpa, Serpent's Glen and Intitjikula. Archaeology in Oceania 35(2):74-81.

\section{Evidence for early focussed marine resource exploitation from an open coastal site in central Queensland}

\section{Sean UIm}

Aboriginal and Torres Strait Islander Studies Unit, University of Queensland, Brisbane, QLD 4072, Australia

Recent excavation of a shell mound on Seven Mile Creek, just south of Gladstone, Central Queensland, has revealed a dense midden deposit dated to 3700 cal BP (Wk-8327). This result provides some of the earliest evidence of highly focussed marine resource exploitation from an open archaeological site on the Queensland coast.
The Seven Mile Creek Mound (KE:A09) sits on a low residual beach ridge fringing Seven Mile Creek, a tributary of Rodds Harbour (Neal 1986). The site is a discrete mound with

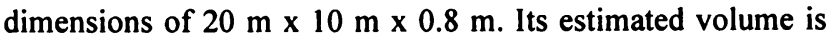
$43.91 \mathrm{~m}^{3}$ based on a digital terrain model.

A single $1 \mathrm{~m}^{2}$ pit divided into four $50 \mathrm{~cm} \times 50 \mathrm{~cm}$ squares (A-D) was excavated into the highest part of the mound. The work revealed an $85 \mathrm{~cm}$-thick single unit of dense shell resting on well-rounded beach sands containing occasional pieces of shell. A total of $1631 \mathrm{~kg}$ of sediment was excavated. Preliminary analysis revealed a deposit dominated by shellfish remains including (in descending order of abundance): rock oyster (Saccostrea commercialis), mud ark (syn. Sydney cockle) (Anadara trapezia), hairy mussel (Trichomya hirsuta), hercules club whelk (Pyrazus ebeninus) and lined nerite (Nerita lineata). Mud crab shell (Scylla serrata), fish bone (including whiting - Sillago sp.) and stone artefacts are present throughout.

Four radiocarbon determinations were obtained for the deposit (Table 1). All dated specimens were articulated mud ark (Anadara trapezia) valves which were plotted in situ during excavation. All samples were subjected to $\mathrm{x}$-ray diffraction (XRD) analysis to confirm the absence of recrystallisation. Conventional radiocarbon ages were calibrated using the CALIB (v4.2) computer program (Stuiver and Reimer 1993). Dates were calibrated using the marine calibration dataset of Stuiver et al. (1998) with a $\Delta R$ correction value of $-5 \pm 35$ (Stuiver and Braziunas 1993). The calibrated ages reported in Table 1 span the $2 \sum$ age-range. All four dates are indistinguishable at the $95 \%$ confidence level. The dates indicate that the site was first occupied around ca. $3700 \mathrm{cal}$ BP and abandoned shortly after $3450 \mathrm{cal}$ BP. The lower two dates (Wk-8327 and Wk-8328) appear inverted, but overlap at one standard deviation. The dates are thus in sequence overall, suggesting extremely rapid accumulation over a period of less than 300 years.

Coastal sites dating to prior to $3000 \mathrm{BP}$ are not common on the Queensland coast (see Ulm et al. 1995). Although several rockshelters containing evidence for marine resource exploitation in the Whitsunday Islands (Barker 1996) and Princess Charlotte Bay area (Beaton 1985) date to the early- to mid-Holocene, only two open sites on the Queensland coast have evidence of focussed marine resource exploitation predating 3000 BP (see Rowland 1999; Walters et al. 1987).

Results from the Seven Mile Creek Mound support the findings of research suggesting widespread residence on the Queensland coast at the time of local sea-level stabilisation (e.g. Barker 1996). Continuing research will seek to address these issues further through detailed analysis of the excavated assemblage and palaeoenvironmental context.

\begin{tabular}{|c|c|c|c|c|c|c|c|}
\hline SQ & $\mathrm{XU}$ & Depth & Lab. No. & Sample & $\begin{array}{l}\delta^{13} \mathrm{C} \\
(\% \circ \mathrm{PDB})\end{array}$ & $\begin{array}{l}{ }^{14} \mathrm{C} \text { Age } \\
\text { (yr BP) }\end{array}$ & $\begin{array}{c}\text { Calibrated Age/s } \\
\text { (cal yr BP) }\end{array}$ \\
\hline A & 4 & $7.14 \mathrm{~cm}$ & Wk-832 & $\begin{array}{l}\text { Anadara } \\
\text { trapezia }\end{array}$ & $-0.9 \pm 0.2$ & $3540 \pm 80$ & $3633(3429) 3237$ \\
\hline A & 13 & $40.44 \mathrm{~cm}$ & Wk-832 & $\begin{array}{l}\text { Anadara } \\
\text { trapezia }\end{array}$ & $-0.8 \pm 0.2$ & $3610 \pm 70$ & $3690(3487) 3338$ \\
\hline A & 20 & $67.84 \mathrm{~cm}$ & Wk-832 & $\begin{array}{l}\text { Anadara } \\
\text { trapezia }\end{array}$ & $-1.2 \pm 0.2$ & $3780 \pm 60$ & $3893(3700) 3548$ \\
\hline A & 26 & $88.24 \mathrm{~cm}$ & Wk-832 & $\begin{array}{l}\text { Anadara } \\
\text { trapezia }\end{array}$ & $-0.5 \pm 0.2$ & $3750 \pm 60$ & $3859(3677) 3485$ \\
\hline
\end{tabular}

Table 1 Radiocarbon dates from the Seven Mile Creek Mound. 


\section{Acknowledgements}

Funding was provided by a Dr Joan Allsop Australian Studies Fund Award from the University of Queensland. I sincerely thank Georgia and Tony Isaacs for permission to access their property and to members of the Gooreng Gooreng community, in particular Cedric and Michael Williams, who encouraged me to undertake the work. I thank Kris Hall (National Parks and Wildlife Service), Maria Cotter, Tony Eales, Joe Firinu, Victoria Francis, Vojtech Hlinka, Karen McFadden, Lad Nejman, Jill Reid and Kim Vernon for help in the field. John Turunen of Keilar Fox \& McGhie Pty Ltd undertook the digital terrain modelling.

\section{References}

Barker, B. 1996 Maritime hunter-gatherers on the tropical coast: A social model for change. In S. Ulm, I. Lilley and A. Ross (eds), Australian Archaeology '95: Proceedings of the 1995 Australian Archaeological Association Annual Conference, pp.31-43. St Lucia: Anthropology Museum, University of Queensland. Tempus 6.

$\rightarrow$ Beaton, J.M. 1985 Evidence for a coastal occupation timelag at Princess Charlotte Bay (North Queensland) and implications for coastal colonisation and population growth theories for Aboriginal Australia. Archaeology in Oceania 20(1):1-20.

Neal, R.A. 1986 Results of the Archaeological Inspection of Proposed Telecom DRCS and Broadband Locations for December 1986. Unpublished report to Telecom Australia.

Rowland, M.J. 1999 The Keppel Islands - 'a 3000 year' event revisited. In J. Hall and I. McNiven (eds), Australian Coastal Archaeology, pp.141-155. Canberra: ANH Publications, Australian National University. Research Papers in Archaeology and Natural History 31.

Stuiver, M. and Brazuinas, T.F. 1993 Modeling atmospheric ${ }^{14} \mathrm{C}$ influences and ${ }^{14} \mathrm{C}$ ages of marine samples to 10,000 BC. Radiocarbon 35(1):137-189.

Stuiver, M. and Reimer, P.J. 1993 Extended ${ }^{14} \mathrm{C}$ data base and revised CALIB $3.0{ }^{14} \mathrm{C}$ age calibration program. Radiocarbon 35(1):215-230.

Stuiver, M., Reimer, P.J., Bard, E., Beck, J.W., Burr, G.S., Hughen, K.A., Kromer, B., McCormac, F.G., Plicht, J. v.d. and Spurk, M. 1998 INTCAL98 Radiocarbon age calibration 24,000 - 0 cal BP. Radiocarbon 40(3):10411083.

Ulm, S., Barker, B., Border, A., Hall, J., Lilley, I. McNiven, I., Neal, R. and Rowland, M. 1995 Pre-European coastal settlement and use of the sea: A view from Queensland. Australian Archaeology 41:24-26.

Walters, I., Lauer, P. Nolan, A, Dillon, G. and Aird, M. 1987 Hope Island: Salvage excavation of a Kombumerri site. Queensland Archaeological Research 4:80-95.

\section{THE ARRAWARRA BEACH STONE STRUCTURE: ANOTHER PERSPECTIVE}

\section{Deborah Vale}

Division of Archaeology and Palaeanthropology, University of New England, Armidale, NSW 2351, Australia

The Arrawarra Beach stone arrangement is located on a rocky platform at the southern end of Arrawarra Beach, approximately $30 \mathrm{kms}$ north of Coffs Harbour on the midnorth coast of New South Wales. The identification of the structure as an Aboriginal fishtrap has been controversial over the last twenty years, its status as an Aboriginal site having changed over time, and numerous lines of evidence have been proposed to settle the issue (Campbell 1978; Coleman 1980; Godwin 1988). Godwin (1988) suggested the analysis of material from an associated midden might provide evidence of the structure's origin and use. Recently, two historical accounts of the use of the structure as a fishtrap by Aboriginal people have been reported (Heron 1994) and further oral evidence has been collected from the Garby Elders (Somerville et al. 1999). In this report I will focus on the analysis of an archaeological fishbone assemblage from the Arrawarra I shell midden (Vale 1998) which has now also provided substantive evidence with which to reassess the structure's status.

The assemblage of fragmented, though well-preserved fishbone was recovered from the Arrawarra I midden, dated to approximately $1,000 \mathrm{BP}$, and located approximately 800 $m$ north of the stone arrangement (Smith 1998). This assemblage consisting of over 60,000 specimens recovered from 6, 3 and $1-\mathrm{mm}$ sieve fractions, was analysed as a single unit (Vale 1998). Eleven taxa were identified in the Arrawarra assemblage (Table 1). Researching the behaviour and habitats of the identified taxa has made it possible to ascertain feasible environments used in obtaining this resource and shed light on procurement strategies.

The use of various fishing technologies can be expected to yield different catches and preservation permitting, different archaeological fishbone assemblages. There is some disagreement about the composition of catches resulting from fish traps (Avery 1975; Campbell 1978; Coleman 1978; Colley 1987; Attenbrow and Steele 1995) and the type of trap proposed as the basis for the models of catch composition is not always made clear. However some specific characteristics could be expected from a trap located in a littoral situation on a rocky platform such as the stone arrangement at Arrawarra. The rocky platform provides food for both herbivorous and carnivorous species and the shallow-water environment would accommodate smaller fish (Lagler 1962) along with small numbers of larger carnivores.

The fishbone assemblage analysed is comprised predominantly of small to medium sized fish with small numbers of larger specimens. Sparidae are represented by the species bream (Acanthopagrus australis) and tarwhine (Rhabdosargus sarba) but not snapper (Chrysophrys auratus), a significant result for identifying fishing environments, as snapper usually occupy reef habitats rather than the estuarine and surf zone habitats of bream and tarwhine. Flathead (Platycephalidae) identified in small numbers should not inhabit a rocky platform as they bury themselves in sand and mud while awaiting prey. However 